\title{
UNDERGRADUATE COORDINATOR: COMPETENCES REQUIRED ACCORDING TO MANAGEMENT PRINCIPLES
}

\author{
http://dx.doi.org/10.5902/2318133863666
}

\author{
Ronison Oliveira da Silva ${ }^{1}$ \\ Antonio Jorge Cunha Campos ${ }^{2}$ \\ Pedro Antônio de Melo $^{3}$ \\ Daniel Nascimento-e-Silva ${ }^{4}$
}

\begin{abstract}
This study aimed to link the necessary competencies to the post of management of undergraduate courses with the four essential phases of the management process: planning, organization, direction, and control. The available scientific literature was analyzed, organized based on semantic and content analysis techniques so that the answers to the guiding questions previously formulated could be visualized. The study points out that the undergraduate coordinator needs to master knowledge from other areas of expertise to act, such as a) analyzing scenarios and generating course production; b) management of materials and services infrastructure, c) leadership, communication, and motivation of your team, and d) assessment of the quality of work and production performed.
\end{abstract}

Key-words: management; competence; management process.

\section{COORDENAÇÃO DE GRADUAÇÃO: COMPETÊNCIAS REQUERIDAS CONFORME O PROCESSO GERENCIAL}

\section{Resumo}

Neste texto relata-se resultados de estudo que teve por objetivo vincular as competências necessárias ao cargo de gerência de graduações com as quatro fases básicas do processo de gestão: planejamento, organização, direção e controle. Analisou-se a literatura disponível, organizada com base nas técnicas de análises semântica e de conteúdo, para que pudessem ser visualizadas as respostas às questões norteadoras previamente formuladas. Entendeu-se que o coordenador de graduações precisa dominar conhecimentos de outras áreas do conhecimento para atuar, tais como análise de cenários e geração de produção do curso; gestão de infraestrutura de materiais e serviços, liderança, comunicação e motivação do seu time e aferição da qualidade do trabalho e da produção realizada.

Palavras-chave: gestão; competência; processo gerencial.

\footnotetext{
${ }^{1}$ Instituto Federal de Educação, Ciência e Tecnologia do Amazonas, Brasil. E-mail: ronison.msc@gmail.com.

2 Universidade Federal do Amazonas, Brasil. E-mail: jorgecampos257@gmail.com.

3 Universidade Federal de Santa Catarina, Brasil. E-mail: pedro.inpeau@gmail.com.

4 Instituto Federal de Educação, Ciência e Tecnologia do Amazonas, Brasil. E-mail: danielnss@gmail.com. 


\section{Introduction}

The studies concerning the magnitude of the work of the coordinators of the undergraduate course after the advent of Ordinance No. 3,183 (Brazil, 2017), which changed the evaluation criteria of the National Institute of Educational Studies and Research - Inep - are still in progress show small in Brazil. There is an understanding that a large part of higher education institutions' success depends directly on the work performed by this professional in the exercise of his position. In this sense, this study aims to list the skills necessary for university course managers according to Administration science's four essential functions (Chiavenato, 2010; Okoye, 2010; Rahman, 2018; Silva, 2019; Ugwu; Chidiebere, 2019).

The coordinators of undergraduate courses are the executives responsible for ensuring the quality of the courses they manage to gradually leverage the concepts assigned by Inep, which is the institute responsible for evaluating and accrediting university courses within the scope of national higher education. In case of a positive evaluation, the faculty receives the legal authorization to continue offering undergraduate courses to new students. On the other hand, unsatisfactory results resulting from this judgment process by Inep lead to the closing of the course, which scratches the faculty's institutional image before its stakeholders.

It turns out that not all professionals who occupy this relevant role in higher education institutions know or master the excellent management practices that make it possible to achieve success in coordinating undergraduate courses. Because they do not understand how these management techniques are applied, they adopt managerial amateurism (Nascimento-e-Silva, 2017; Romme, 2016). It is equivalent to the firefighter figure who lives "putting out fires", that is, he only acts after the occurrence of problems that negatively impact its performance due to its reactive posture to the difficulties and challenges inherent to its function. As this professional does not know the basic principles of management, his routine consists of resolving a palliative and the unsustainable way the situations presented to him. Usually, after they have caused some damage to the institution in which he works, or even to the students.

In this sense, the present study aims to list the skills necessary for undergraduate course managers to perform this activity with high excellence levels. To this end, we sought to establish the link between these competencies and the four fundamental management premises: planning, organization, direction, and control. It is understood that the exercise of these skills will maximize the performance of these professionals. It occurs in terms of the challenges and demands inherent in the daily work in the coordination of undergraduate courses.

The study is justified for two reasons. The first came after a survey by the authors of this production, which found that the literature concerning the undergraduate coordinator's performance is still lacking. Perhaps this is a consequence of the recent legal change (Brazil, 2017) that raised the requirements to be met by institutions offering undergraduate courses. The second reason was the effort to collaborate with the spread of management techniques and practices, which can be applied both by administrators and other professionals who hold management positions at universities. From the professionalization 
of these educational organizations' management, the quality of undergraduate courses tends to increase. It will probably contribute to university institutions' survival, striving for continuous improvement (Paraschivescu; Cotîrlet, 2015) of their stakeholders' services. It characterizes the complex and changing environment (Kanan; Zanelli, 2011).

\section{Management: conceptual scope}

Management is a vital instrument for the government to achieve institutional objectives (Rahman, 2018) successfully. The use of the term "vital" demonstrates the magnitude of the management principles for a municipality, state, or country to implement its projects successfully. In summary, without professional management, the achievement of any objective is compromised, not only due to the absence of adequate strategies but also due to the lack of control of resources necessary for the accomplishment of the intended purpose (Mazzarol; Clark; Reboud, 2014; Oliveira, Nascimento-e-Silva, 2020).

To manage has the meaning of being efficient with due obedience to the legal dictates inherent to the exercise of the administrator's function (Oliveira; Silva; Duarte, 2015). In these authors' view, before thinking about achieving the intended objectives, the manager must strictly respect all the rules inherent to fulfilling his organization's function (Nascimento-e-Silva, 2011). With this definition, to assume a managerial position, it is necessary to understand two sets of information: what are the intended intentions and which laws, rules, ordinances, and other legal provisions must be observed, organizational goals can be achieved ethically and transparently.

Management is the basis of each institution (Ugwu; Chidiebere, 2018). According to this statement, throughout history, the administration has helped substantially in human civilization's progress. Without the correct management practice, the world would hardly reach the advanced level of evolution that is remarkable today. Not only humanity but also organizations are in constant change and dynamism, in which the master principles of management are vital (Rahman, 2018) for their survival in their respective fields.

The act of managing consists of planning, organizing, directing, and controlling resources (Biasioli, 2018; Nascimento-e-Silva et al., 2013; Silva, 2019) The reason that justifies the accomplishment of these four steps described is the achievement of defined objectives by the organization (Nascimento-e-Silva, 2011). In a similar view, achieving goals correspond to the manufacture of a product. It is only possible if the raw material needed for such action is managed with mastery. What characterizes the resources is their scarcity (Oliveira; Nascimento-e-Silva, 2020), which justifies why they need to work.

Management consists of collective activity carried out to achieve common goals (Okoye, 2010). This view is complemented by Nascimento-e-Silva (2011) conceptualization, which points out that an organization is any grouping formed by two or more people who work towards achieving the same purpose. A classroom, a company sector, a family, a church, and a football team are examples of organizations. Regardless of your industry, what determines an organization's success or failure is its ability to turn its plans into positive results. It is possible through the continuous and assertive practice of the four functions that make up the management process: planning, organization, direction, and control. 
The scientific literature concerning management points out in its definitions that it consists of a process (Albuquerque et al., 2018; Brito et al., 2020). Every function is composed of sequential steps that, in the end, generate a result. The parts that integrate the management process are planning, organizing, directing, and controlling. It is the assertive practice of these described steps that maximize the probability of success of the organization (Nascimento-e-Silva, 2011). One of the reasons for a public or private institution's failure is the malpractice concerning these four stages of the management process, which must consistently and sustainably materialize the organizational objectives.

To manage means to plan, organize, direct, and control the available resources to achieve organizational objectives. It is the correct application of these four functions (planning, organizing, directing, and controlling) that integrate the management process that maximizes the use of resources and maximizes the probability of achieving its goals. Failure to observe these basic precepts does not generate any result other than managerial loss, which avoids all organizational sphere costs.

\section{Competence}

Competence is a concept that encompasses the skill and knowledge that are conditioning factors for the achievement of a specific purpose (Ratminingsih; Budasi; Kurnia, 2020; Teodorescu, 2006). In other words, whoever has the necessary knowledge to develop a particular activity and demonstrates skill demonstrates their competence. This first definition can be interpreted in another way: whoever has the theoretical and practical knowledge concerning a given activity manages to obtain a satisfactory performance about its realization.

It appears that competence is a set of intelligent initiatives taken by an individual in the organization who has responsibilities to fulfill (Agus et al., 2016; Yusnita et al., 2018). This set of actions is considered a conditioning factor for that the professional performs his job satisfactorily. Competence is the idea of a group of knowledge, without which the individual cannot be as competent (Yusnita et al., 2018).

The term competence represents the completeness of the knowledge, skills, actions, and motivations required to perform tasks and overcome challenges inherent to a given job (Armstrong; Taylor, 2014; Solga; Ryscha. Mattenklot, 2011). That competence can be considered the result of the combination of theoretical and practical knowledge, which are essential for accomplishing a job or a set of tasks related to a field of activity. In other words, conceptual understanding needs to be applied. The result corroborates for the professional to recognize excellence due to an activity's skill and quality.

Competence is the gathering of knowledge, skills, and attitudes that make it possible to carry out significant positions and activities for an organization (Lai, 2004). With this definition, competence is the aggregation of theoretical elements, which need to be handled in an agile and productive way to fulfill a task's purpose or ensure a result's achievement. The knowledge, skills, and attitudes directly influence the employee's performance, reinforcing the need for leaders and managers to assertively know their followers' profile (Sari, 2019). It is necessary so that the team members' qualities are enhanced. Simultaneously, the points that may need reinforcement are worked on to achieve the improvements (Paraschivescu; Cotîlet, 2015) necessary for their personal and professional development.

Regae: Rev. Gest. Aval. Educ. Santa Maria

v. 10

ก. 19

e63666, p. 1-17

2021 
Competence encompasses the professional's knowledge, skills, attitudes, and experiences (Kuivila et al., 2019). In this context, knowledge covers all useful information that contributes to raising the individual's intellect level. The skills correspond to the person's talent to logically and orderly handle this knowledge to achieve a particular purpose. Attitudes result from the acquisition of new knowledge, which, when practiced, are reflected in new habits. The experiences resulting from the subject's attitudes and the environment in which this individual lives, and how he intervenes in his living environment.

The development of specific activities requires the combination of the following elements: a) knowledge; b) skill; c) disposition; d) values (Gonczi, 2013). This list is a logical, procedural scheme (Albuquerque et al., 2018; Brito et al., 2020; Silva., 2019). Knowledge represents the first necessary element that a subject must have to perform a specific job. With this knowledge, the next step is to develop the practice of this knowledge. It enhances the skills that the individual has. The disposition and values represent both the energy needed to perform a task and the ethical use of these skills in a healthy way and within the existing normative parameters.

For the present study, competence is a set of knowledge, skills, and attitudes that, when employed, enable a professional to perform a particular activity or to perform a position in an organization. Learning can be implicit and is present inside people, while explicit knowledge represents accessible data and information. Skills are the handling of knowledge in orderly practices, the creation of which generates an intended result. Attitudes are the internalization of knowledge. It internalizes and reflects in new attitudinal patterns, which gradually replace the old ways of behavior once considered ideal.

\section{Methodological procedures}

This study is based on the conceptual bibliographic method developed by Nascimento-e-Silva $(2021 ; 2020)$. It consists of a set of editorial techniques whose logic is procedural, which in other words means that each step must be logically and sequentially so that, in the end, the expected result materializes in practice (Silva, 2019). The method had four phases: a) definition of the research questions; b) data collection; c) organization and analysis of data and; d) generation of responses (Nascimento-e-Silva, 2012; 2020).

The questions defined for the realization of this textual construction were: a) "What is a management process?", and b) "What is competence?". With these questions in mind, the next step was to locate the answers to the guiding research questions (Brei; Vieira; Matos, 2014). This process was carried out by consulting the Google Scholar and Science Direct databases. The reason that led to these two databases was the following: when the answers were not found in their entirety in Google Scholar, the studies present in Science Direct were used. Preferably, the selected studies should be dated between 2014 and 2019. The texts from years before this time were a complementary reference to compose this study's theoretical framework. The localized responses started with phrases like "Competence is", "Planning can be considered as" and "Direction consists of", always with the same logic: the researched concept followed by a complement that gives it the aspect of singularity.

The third phase of the conceptual bibliographic method was to organize the data obtained. For this, two editorial techniques we used: the first one uses a reference framework called the mass of data. In this table, both the references about each study 
cataloged in the previous research stage inserted, and responses transcribed in a literal manner accompanied by their respective page numbers. The next procedure adopted was analyzing the terms of equivalence present in each statement collected (Nascimento-eSilva, 2020). Through this technique, it was possible to observe each answer's underlying logic and perceive the main similarities and differences in the phrases referring to each researched concept.

The last step was to generate the answer to the guiding research questions (Brei et al., 2014). For the development of each topic of the study, the following scheme we used: each answer was interpreted and rewritten using indirect citations to convey the ideas that each author sought to disseminate with his concepts. The final part of the study was produced by correlating each stage that makes up the management process (planning, organization, direction, and control) with the skills necessary to develop each phase in coordinating graduations (Inep, 2017; Silva, 2019). We adopted a mind map production to facilitate the fixation of the contents present in this last section of the study that precedes the conclusion (Rachmawati; Nugrahaeni; Mauludiyah, 2020). This specific type of map is an efficient solution, both for representing management plans and the disclosure of the articulation of concepts that interact to form a conceptual whole, as is the case represented in the present study.

\section{Competences required for undergraduate coordinators}

Here, the necessary competencies for undergraduate coordinators will be listed so that these officers can perform their roles with excellence. The knowledge that consistently meets the demands inherent to the position is on four pillars. These steps are planning, organization, direction, and control (Nascimento-e-Silva et al., 2013; Silva, 2019). These activities' continued practice increases the likelihood of reaching organizational objectives, especially within universities, whether public or private.

\section{The planning process: the coordinator as a strategist}

Planning is the first phase of the management process, which consists of the objective-strategy binomial. The objective is a future state to be reached, which, in other words, means to say where the organization wants to go. The strategy, on the other hand, concerns the path chosen to achieve the intended purpose. In other words, strategy means that the organization needs to define what it will do to reach the place, point or state it is aiming for in the future (Nascimento-e-Silva, 2017; Silva, 2019; Palhas, 2019).

However, before defining the objective and strategy, it is opportune to carry out a scenario analysis of its internal and external environments. In management, this analysis is called the Swot Matrix (Abdel-Basset; Mohamed; Smarandache, 2018; Kumar, Sangwan; Nayyar, 2020). The term Swot corresponds to each element's initials' acronym that constitutes this analytical instrument in management.

The letter S comes from Strength, which means strongholds, which represents what an organization does best and makes it unique and differentiated when compared to its competitors. In turn, the $\mathrm{W}$ means weaknesses, which are the activities carried out by the corporation whose performance is deficient. The $\mathrm{O}$ stands for Opportunities, which covers the occasions that can benefit a company's performance. And the $T$ is the threats, which are situations that can hinder the achievement of the intended objective (Canham; Wister; 
O'Dea, 2019; Temel et al., 2018). Regarding the components that make up the Swot Matrix, the study undertaken by Temel et al. (2018) considers that Opportunities and Threats are elements of the internal environment that the manager is unable to control. On the other hand, strengths and weaknesses can be worked on and enhanced to achieve continuous improvement (Paraschivescu; Cotîrlet, 2015) in the organization's processes.

With this analysis's results in mind, the next step in planning is to turn objectives into goals. In summary, Nascimento-e Silva (2017) explains that goals are objectives measured through quantitative data. Let us look at an example: imagine that a university aims to increase the scientific production of its faculty: this is an objective; however, it is still something vague. It is necessary to define each teacher's execution plan who will participate in this endeavor with goals and deadlines for completing scientific articles according to the availability of time for each teacher (Nascimento-e-Silva, 2017).

After defining the triad formed by objective, strategy, and goal, it is necessary to register all this in a management plan. The plan needs to respond in an uncontested manner: a) what the organization wants and when it will achieve; b) what goals it proposes to achieve; c) what it will do to reach the desired point. In an organization, everyone must know what their function's objectives are. These intentions will contribute to accomplishing something more significant: the continuity of the enterprise's activities in their respective operating environment. In the planning stage, the undergraduate coordinator must act as a scenario analyst, who, before executing the management plan, analyzes the internal and external aspects inherent to his action scope (Canham et al., 2019; Temel et al., 2018).

\section{The organizing process: the coordinator as a resource manager}

The second master principle of management is organizing, which deals with resources (Oliveira; Nascimento-e-Silva, 2020). All objectives to be materialized will necessarily consume resources, which are the means used to produce something or something (Nascimento-e-Silva, 2011; Silva et al., 2019). An inherent feature of resources is their scarcity since there are no resources in abundance. It is the major challenge for undergraduate coordinators: to achieve the goals of their function with the few existing resources.

Before carrying out the work, a detailed survey of each resource necessary to achieve the intended objective in the organization process. The challenge is to determine what resources are already available and pending to be purchased, negotiated, or contracted. By adopting this procedure, the institution avoids making unnecessary acquisitions, which is a waste (Billig, 2016). The best way to prevent waste is to prevent it from being generated (Castigliego et al., 2019). It is a thought aligned with the principles of continuous improvement (Paraschivescu; Cotîlet, 2015), more precisely with the austere combat to any indication of activity that does not add value to the processes developed by a corporation. Another advantage of this survey is monitoring the negotiations and the prospecting of each resource necessary to materialize the intended objective (Becheru; Bădică, 2019; Payne, 1994).

It is essential to highlight the relevance of accountability in the organization process (Alagrash et al., 2019). In management, everything must be recorded. This logic also applies to all purchases of products and services made to comply with the management plan. Any operation in this sense must be accounted for, even if no resources to achieve

\begin{tabular}{|l|l|l|l|l|l|}
\hline Regae: Rev. Gest. Aval. Educ. & Santa Maria & v. 10 & n. 19 & e63666, p. 1-17 & 2021 \\
\hline
\end{tabular} 
the desired goal. Managing is not an action that is restricted only to the scope of organizational intent. It is necessary to comply with the legal procedures inherent to the corporate environment to ensure the required governance for any management or coordination position in organizations (Dixit, 2009).

For the execution of proactive resource management, the coordinator has the necessary minimum skills in Materials Management (Owusu; Aigbavboa; Thwala, 2015; Oliveira; Nascimento-e-Silva, 2020), Logistics Management (Atanasoki; Esmerova, 2019), and Accounting (Surnani; Ambarriani, 2019). The reason for dominating these areas is the challenges inherent in this stage of the management process. Among the relevant tasks in the management of resources, the following stand out: a) check the availability of the resources required for the desired objective; $b$ ) negotiate prices and delivery times for the acquisition of goods and services; c) register and inventory assets; d) enter and inspect contracts; e) account for the resources that have been consumed, among others.

When there is no monitoring of resources, the institution runs the risk of finding out if it is missing during the tasks' execution, which will delay the work's progress. It will end up compromising the achievement of the objectives set. It is an evident symptom of managerial amateurism (Nascimento-e-Silva, 2017), typical of those who manage their tasks according to the circumstances. Although it seems obvious, many organizations fail to perform this step by failing to follow these necessary procedures, culminating in organizational failure.

\section{The directing process: the coordinator as a people manager}

The management stage deals with what is most important in an institution: people (Silva, 2019), while leading them is a daily challenge. It is due to the following fact: everyone has his personality, preferences, convictions, beliefs, tastes, and opinions, but he is also the holder of his talents and qualities. These positive points will be maximized if the goals are achieved effectively. Since organizations are human groups that work towards a common goal, every manager must enjoy dealing with people. To know how to deal with and work with his team members (Nascimento-e-Silva, 2011), since they are the ones who make it possible to construct results in the organizational scope.

At this stage of the management process, it is necessary to establish three types of schemes. The first of them the leadership (Reardon et al., 2019), in which the coordinator of degrees must define how to deal with his audience, that is, teachers, students, technicians, and the public). Through his power of influence, the coordinator will allow his team members to carry out their tasks naturally, without the need to be continuously reminded of their activities' delivery.

The permanent challenge of exercising leadership (Reardon et al., 2019) is to exercise it to gain trust (D'Ávila, 2016) both from your team members and from professionals in other departments of the institution of higher education. It requires interpersonal and relational skills, which must be continually improved. One of the factors capable of making organizations respond consonantly to the challenges inherent to their market environment is their leaders' consistent performance. They are the ones who guide, lead, supervise, and evaluate the result from the production of each task performed during the management plan. 
This stage's second scheme is towards communications (Behrens; Noteboom; Bishop, 2019). In the management plan's execution, the exchange of information regarding the processes' progress is constant and necessary. The utility of this scheme aims to a) monitor whether the tasks are being carried out as planned, b) warn about any problem that happens during the work to seek the best solution for it on time and avoid any negative impact during the management plan and c) enable leaders to communicate any, and all information considered relevant regarding the performance of the execution of the management plan and the achievement of the proposed goals. It is essential that in this scheme everyone knows what to do, how they will do it when they deliver, how much will produce, how they will work, among other details.

In this sense, Nascimento-e-Silva et al. (2013) highlight communication types that must exist in organizations whose management is not improvised. In a university, communication must be: a) ascending: which is the flow of information from students, professors and administrative technicians to university heads; b) descendant: which is the reverse - the dialogue between managers and their followers; c) lateral: students, teachers, managers, directors and administrative staff with their appropriate peers; d) diagonal: which represents the communicational interface existing between the different positions and levels of the institution, and finally, e) environmental: which is the interaction of faculty members with other institutions and other stakeholders from the external environment of the organization.

The third scheme is the motivation (Yahia et al., 2019), which aims to keep all participants in the management plan engaged so that the objectives cease to exist only in the field of ideas to realize. Here the leader must assume the role of enthusiasm of his team and make sure that they maintain a satisfactory level of performance in the execution of their tasks. It is possible through the concatenation of the two schemes previously proposed: a charismatic leader will know how to use his influence to communicate correctly with his team and maximize the potential that each must materialize the goals and, consequently, the organizational objectives (Nascimento-e-Silva, 2017).

Most leaders make mistakes when dealing with people because it feeds the vain illusion that it is possible to control people when what is controllable in organizations are processes, objectives, and results. Management is done with people because an organization to exist. Two or more individuals must coexist to achieve a common end (Nascimento-e-Silva, 2011). Here, the course coordinator must be a leader, communicator, and motivator to establish a dialogical and assertive relationship with the people on his team and achieve the organizational objectives, which depend on the sum of the efforts and talents of each of the plan's executor's management in the organization, as well as the strategies employed.

To act as a motivator, communicator, and leader of your team, the undergraduate coordinator needs to have solid knowledge in areas of expertise related to human development. Among the knowledge about people's strong understanding, Psychology, Neurolinguistic Programming, Public Speaking, People Management, and Interpersonal Relationships stand out.

As people are the most challenging resource to be managed in organizations, the coordinator of higher education courses must continually learn how to deal with human resources (Chiavenato, 2010; Sondari; Zaimar, 2019). It is opportune to emphasize that 
the coordinator is the link that unites ordinary objective different nuclei of a university. Among these groupings, the teaching staff, the structuring teaching nucleus (NDE from the acronym in Portuguese), the students, the course collegiate, and the institution's administrative staff stand out (Abmes, 2018).

\section{The controlling process: the coordinator as a quality checker}

Controlling consists of verifying that all activities defined in the planning, organization, and direction stages follow the management plan content. It ensures the maximum unity between the planned and the performed. The purpose is to demonstrate that the plan's tasks are carried out with the level of quality considered ideal (Nascimento-e-Silva, 2017; Silva, 2019). This fourth basic principle of management science aims to prevent possible failures during the management plan's execution. If the predicted errors occur, corrective measures must be taken promptly. This management process phase consists of 4 subitems: standardization, measurement, evaluation, and replanning (Silva, 2019).

Standardization exists to define what will be the standard (Nascimento-e-Silva, 2017) to be adopted in the execution of the necessary activities) to reach the organizational objectives. The establishment of reference standards is relevant. The tasks to be performed must refer to the measures adopted, with their respective specifications and attributes. It will make the products (delivered to the end customer follow) an execution logic, which will be a faithful representation of the adopted models.

Regarding the measurement, it is necessary to understand that all organizational tasks are mandatorily measured because, without this, the development of management is compromised. The measuring means defining the quantities of products in each of the functions performed during the management plan's execution (Silva, 2019). Measurement is through the definition of indicators (Nascimento-e-Silva, 2017), which will show whether the results obtained are following those planned. The logic to be used here is simple: the outcome of each task's production must be congruent with the quantities to be delivered. The fidelity between the estimated production and the result will define whether the management process's execution was successful or was deficient.

In turn, the evaluation (Sari, 2018) consists of comparing the produced with the adopted standard (Nascimento-e-Silva, 2017). The ideal scenario to be considered is products delivered with the idealized quality and the quantities necessary to achieve the organizational objectives. The evaluation examines the produced in its quantitative and qualitative aspects. Here, there are only two possibilities: the achievement of goals or the non-fulfillment of them, which raises the need to identify the causes that generated the negative effect on the plan's execution and approval by the Higher Education Institution.

When the result achieved in the execution of the tasks is below the expected, it is necessary to perform the replanning (Bagni; Marçola; Andrade, 2018), the last sub-phase of the control process. In summary, to redesign is to redo, and this includes both the plan and its execution. Naturally, elaborating the new version of the management plan and defining the tasks necessary to achieve the objective should strive for more outstanding care to avoid a recent failure.

Successful organizations know how to identify where they are going wrong and can recover on time, as they seek continuous improvement of their processes (Paraschivescu; Cotîrlet, 2015). It is possible through a control scheme that considers the coexistence of 
the four items above (mentioned). Through the measured results, the organization will identify the productivity and quality of everything it produces. It is necessary because a management plan's execution demands resource consumption (Oliveira; Nascimento-eSilva, 2020). And the non-achievement of organizational (goals) causes the waste of material, time, money, production, technology, and other (resources) employed in the execution of the management plan (Billig, 2016). The undergraduate coordinators should keep in mind that Administration is not an isolated science.

On the contrary: it dialogues with other branches of knowledge. From this dialogical interface between sciences, the necessary competencies for the administrator's full and safe performance in his professional environment arise. It requires an expanded view of the magnitude of his role in the organization's survival. For future work, we suggest a survey in the general regulations of public universities in the North Region on the director's duties in these respective institutions of higher education and their link with strategic management and innovation.

Higher education institutions are organizations located in an environment that is notable for the high degree of uncertainty and changes (Kanan; Zanelli, 2011). In addition to seeking the development of strategies that allow them to achieve positive results in their institutional mission to train people, these organizations need to be aware of the universe of legal regulations to which they are subject. One of these laws is the one that takes care of the approval processes for new higher education courses and the recognition or renewal of award of existing degrees (Brasil, 2017).

When aspects such as planning, organization, direction, and control, the probability of managerial failure becomes high (Nascimento-e-Silva, 2017). For this reason, the present study recommends that occupants of administrative positions in higher education institutions continuously develop in terms of learning management techniques that allow them to perform their functions with skill and quality (Slack; Chambers; Johnston, 2009). Usually, colleges and university centers' daily life points to teachers who unequivocally know their area of training but who need to balance this notorious knowledge with the managerial tasks inherent to management positions (Vignati, 2019). In this sense, the term competence treated in this study is a skill that can be internalized and practiced in the daily lives of education professionals with a view to its constant improvement (Graban, 2013). Figure 1 summarizes the knowledge disseminated in this part of the present study. 
Figure 1 -

Necessary skills for the coordinators of degrees according to the management process.

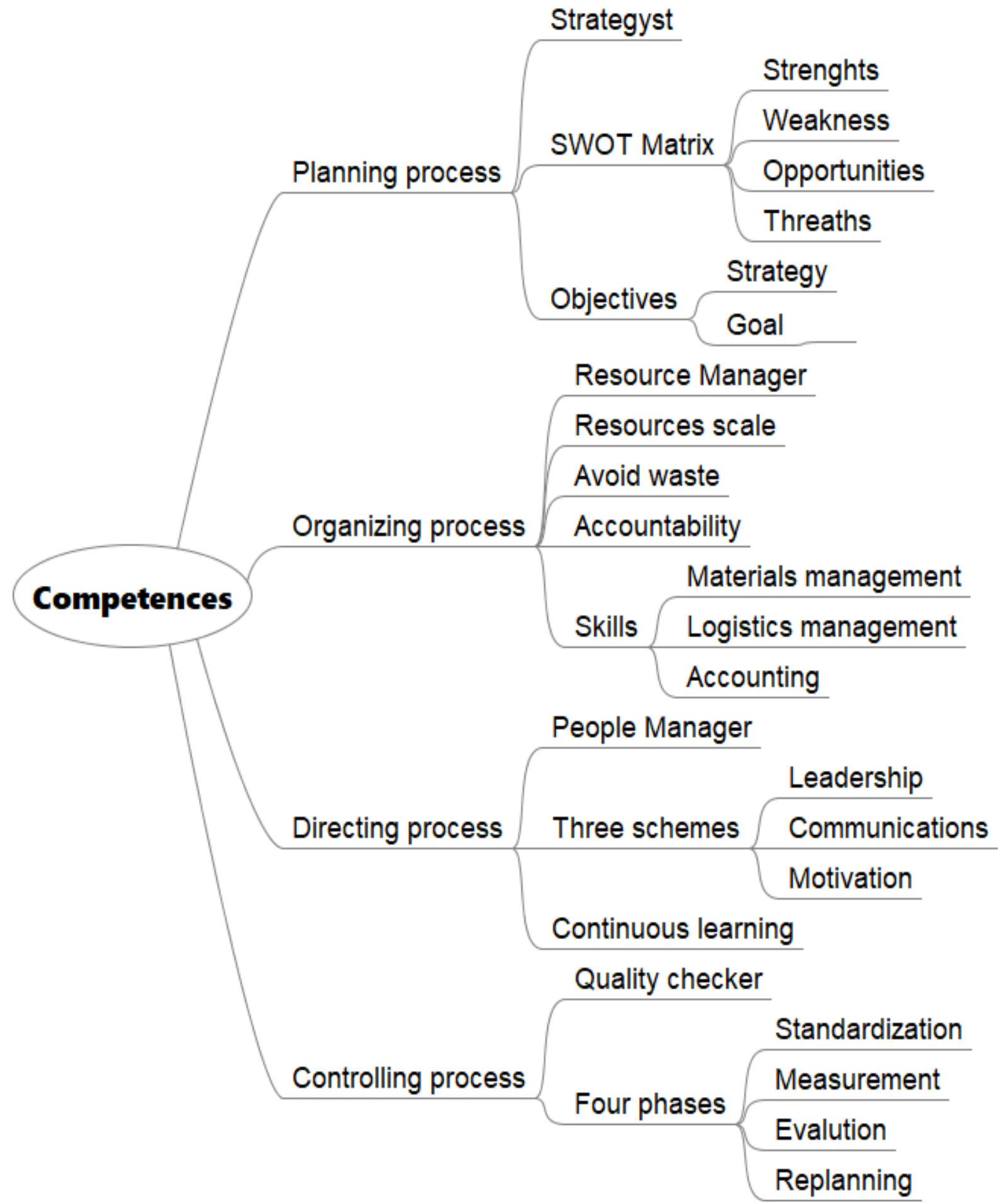

Source: Prepared by the authors.

Thus, the present study implies that learning both the management process and the skills inherent to each phase that structures this process can be considered a significant factor for success in conducting the position of graduate coordinator. It is necessary not only to comply with the accrediting body requirements for higher education in Brazil but 
also to ensure that these degrees' management is carried out in a more organized and professional manner (Romme, 2016). The coordinator is the guiding thread responsible for catalyzing and diligently managing teachers, pedagogues, administrative staff, and other people directly involved with the quality of teaching and learning processes in higher education. The more refined this officer's performance, the greater the likelihood of success in fulfilling university institutions' primary mission. It is to train people able to work in their respective professional fields.

\section{Conclusion}

According to the four phases of the management process, this theoretical essay showed that the competencies include knowledge from other Administration's science areas. The constant exercise of these competencies will make the directors of undergraduate courses able to act in an assertive and precise manner in achieving the related organizational objectives and goals (to the position of course coordinator in the HEls). At the beginning of this study, the managerial improvisation will gradually adopt acceptable management practices present in management. If well applied, it considerably increases the probability of success in administrative functions, including the coordinator of undergraduate courses.

How it is possible to perceive the adequate performance of higher education courses' coordination activities requires much more than knowledge about the subjects concerning the subjects that make up a degree. In this study, the coordinators highlighted to be successful in their duties must continuously practice management science's master principles. It is made possible through the competencies related to each stage that make up the management process. The whose expected result is the sustainable and consistent achievement of organizational objectives. For future studies, we suggest an investigation regarding the directors of university institutions' perception regarding the system for evaluating degrees adopted by the Inep.

\section{References}

ABDEL-BASSET, Mohamed; MOHAMED, Mai; SMARANDACHE, Florentin. An extension of neutrosophic AHP-SWOT analysis for strategic planning and decision-making. Symmetry, Basel, v. 10, n. 16, 2018, p. 1-28.

ABMES. Cenários da educação superior no Brasil: reflexões sobre a nova legislação e os novos instrumentos de avaliação. Brasília: ABMES, 2018.

ALAGRASH, Yasamin; ALGHAYADH, Faisal; ALSHAMMARI, Ahmad; DEBNATH, Debatosh. Cloud computing: a framework for balancing accountability and privacy based on multi-agent system. CYBERSECURITY AND CYBERFORENSICS CONFERENCE, 2019. Melbourne: CCC, 2019.

ALBUQUERQUE, Angelita do Socorro França; MORAIS, Maria Amélia de Souza; LIMA; Marcelo; NASCIMENTO-E-SILVA, Daniel. Processo de institucionalização: um estudo sobre a experiência do espaço da cidadania ambiental (ECAM). Review of Research, Maharashtra, v. 7, n. 9, 2018, p.1-13.

ARMSTRONG, Michael; Taylor, Stephen. Armstrong's handbook of human resource management practice. London: Kogan Page, 2014. 
ATANASOKI, Drashko; ESMEROVA, Emanuela. Graphic displays of managerial business logistics. Anglisticum Journal, Tetovo, v. 8, n. 8, 2019, p.23-32.

BAGNI, Gustavo; MARÇOLA, Josadak Astorino; ANDRADE, José Henrique de. Desenvolvimento e implementação de um novo modelo de plano mestre de produção (MPS) para uma empresa fabricante de material de escrita. Facef Pesquisa: Desenvolvimento e Gestão, Franca, v. 21, n. 2, 2018, p. 197-210.

BEHRENS, Andrew; NOTEBOOM, Charlie Bakker; BISHOP, David. How can heath tecnology project communications be improved in a hospital. In: Proceedings...Midwest (MWAYS), Oshkosh, Wisconsin, 2019.

BIASIOLI, Renata Maria. Diagnóstico da participação dos servidores técnicosadministrativos (TAs) das coordenações de cursos de graduação do centro de educação e ciências humanas da UFSCar. São Carlos: UFSCar, 2018. 84f. Dissertação (Mestrado em Gestão e Organizações e Sistemas Públicos). Universidade Federal de São Carlos.

BILLIG, Osvaldo Alencar de Oliveira. Restrições e perdas no contexto do transporte rodoviário de cargas: um estudo de caso. Caxias do Sul: UCS, 2016. 98f. Dissertação (Mestrado em Administração). Universidade de Caxias do Sul.

BRASIL. Portaria n. 3.183 de 31 de outubro de 2017: aprova em extrato os indicadores do instrumento de avaliação de cursos de graduação para os atos de autorização, reconhecimento e renovação de reconhecimento nas modalidades presencial e a distância do Sistema Nacional de Avaliação da Educação Superior - Sinaes. Brasília: MEC, 2017.

BREI, Vinícus Andrade; VIEIRA, Valter Afonso; MATOS, Celso Augusto. Meta-análise em marketing. Revista Brasileira de Marketing, São Paulo, v. 13, n. 2, 2014, p. 84-97.

BRITO, Zenóbia Menezes de; NASCIMENTO-E-SILVA, Daniel; SOARES, Marison Luiz; SOARES, Melissa Meller. Processo Gerencial: uma análise para suporte à gestão em uma instituição federal de ensino. Anais... COLÓQUIO INTERNACIONAL DE GESTIÓN UNIVERSITARIA, 16, 2016. Anais ... Arequipa: Cigu, 2016.

CANHAM, Sarah; WISTER, Andrew; O'DEA, Eireann. Strengths, weakness, opportunities, and threats to housing first in Metro Vancouver. Evaluation and Program Planning, Vancouver, v. 75, 2019, p. 69-77.

CASTIGLIEGO, Joshua R; WALSH, Michael J; POLLACK, Adam; CLEVELAND, Cutler J. Carbon free Boston: waste technical report. Carbon Free Boston. Waste techical repport 2019. Boston: Boston University, 2019.

D'ÁVILA, Paolo Rosi. Liderança, qualidade de troca social em equipes de trabalho e o comprometimento organizacional: um estudo com peacekeepers brasileiros no Haiti. Rio de JaneiroFGV, 2016. 416f. Tese (Doutorado em Gestão da Administração Pública). Fundação Getúlio Vargas.

DIXIT, Avinash. Governance institutions and economic activity. American Economic Review, Washington, v. 99, n. 1, 2009, p. 5-24.

GONCZI, Andrew. Competency-based approaches: linking theory and practice in professional education with particular reference to health education. Educ. Philos. Theory, London, n. 45, v. 12, 2013, p. 1290-1306.

GRABAN, Mark. Hospitais Lean. Porto Alegre: Bookman, 2013.

INEP. Instrumento de avaliação de curso de graduação Presencial e a distância: reconhecimento, renovação de conhecimento. Brasília: Inep, 2017. 
KANAN, Lilian Aparecida; ZANELLI, José Carlos. Características do trabalho de coordenadores de curso no contexto universitário. Revista Espaço Pedagógico, Passo Fundo, v. 18, n. 1, 2011, p. 151-170.

KUIVILA, Heli-Maria; MIKKONEN, Kristina; SJÖGREN, Tuulikki; KOIVULA, Meeri; KOSKIMÄK, Minna; MÄNNISTÖ, Merja ; LUKKARILA, Pirjo; KÄÄRIÄINEN, Maria. Health science student teacher's perceptions of teacher competence: a qualitative study. Nurse Education Today, v. 84, 2020, p. 1-7.

LAI, Linda. Strategisk kompetansestyring. Bergen: Fagbokforlaget; 2004.

MAZZAROL, Tiim; CLARK, Delwyn N; REBOUD, Sophie. Strategy in action: case studies of strategy, planning and innovation in Australian SMEs. Small Enterprise Research, Sydney, v. 21, 20104, p. 54-71.

NASCIMENTO-E-SILVA, Daniel. Gestão de organizações de ciência e tecnologia: ferramentas e procedimentos básicos. Saarbrücken: Novas Edições Acadêmicas, 2017.

NASCIMENTO-E-SILVA, Daniel. Compreendendo o processo gerencial. Manaus: Ifam, 2011.

NASCIMENTO-E-SILVA, Daniel. Manual de redação para trabalhos acadêmicos: position paper, ensaios teóricos, artigos científicos, questões discursivas. São Paulo: Atlas, 2012.

NASCIMENTO-E-SILVA, Daniel. Manual do método científico-tecnológico: versão sintética. Florianópolis: DNS, 2020.

NASCIMENTO-E-SILVA, Daniel; SIMÕES, Chiara da Silva; SOARES, Márison Luiz; PEREIRA, Ana Maria Alves. Proposição de uma sistemática de avaliação de aprendizagem na formação de administradores com base no processo gerencial. Rev. Adm. Universidade Federal de Santa Maria, Santa Maria, v. 6, n. 4, 2013.

OLIVEIRA, Erinaldo Silva; NASCIMENTO-E-SILVA, Daniel. Gerenciamento participativo de recursos em espaços pedagógicos. Regae: Rev. Gest. Aval. Educ., v. 9, n. 18, 2020, p. $1-17$.

OLIVEIRA, Marcelo Martins de; SILVA, Sabrina Soares da; DUARTE, Gabriela Rezende. O uso do sistema de registro de preços para execução de obras e serviços de engenharia no município de Lagoa da Prata/MG. Revista Gestão Pública Práticas e Desafios, Recife, v. 8, n. 2, 2015, p. 1-14.

PALHAS, Gonçalo da Cruz Pardal. Proposta de BSC como sistema de controlo de gestão numa empresa de peritagens do sector automóvel. Lisboa: UL, 2019. 43f. Dissertação (Mestrado em Ciências Empresariais). Universidade de Lisboa.

PARASCHIVESCU, Andrei Octavian; COTÎRLET, Paul Claudiu. Quality continuous improvement strategies kaizen strategy - comparative analysis. Economic Transdisciplinary Cognition, Bacau, Romania, v. 8, n. 1, 2015, p. 12-21.

PAYNE, Adrian. Relationship marketing making the consumer count. Managing Service Quality, v. 4, 1994, p. 29-31.

RACHMAWATI, Miatin, NUGRAHAENI, Fitria, MAULUDIYAH, Lailatul. Improving Arabic speaking through mind mapping strategy. Izdihar: Journal of Arabic Language Teaching, Linguistics, and Literature, v. 3, n. 1, 2020, p. 31-44.

RAHMAN, Most Sangida. Women's participation in Administration: an analysis on Police Administration in Bangladesh. Humanities and Social Sciences, v. 6, n. 6, 2018, p. 182187. 
RATMININGSIH, Ni Made; BUDASI, I Gede; KURNIA, Wira Dharma Asha. Local culturebased storybook and its effect on reading competence. International Journal of Construction, Hong Kong, v. 13, n. 2, 2020, p. 1-16.

REARDON, Robert; FITE, Kathleen; BOONE, Mike; SULLIVAN, Sierra. Critically reflective leadership: Defining successful growth. International Journal of the Whole Child, Murfreesboro, v. 4, n. 1, 2019, p. 20-32.

ROMME, Georges. The quest of professionalism: the case of management of entrepreneurship. Oxford: Oxford University Press, 2016.

SARI, Yeni Permata. Relationship of work motivation with employee performance in the office of education and youth education department of Solok District. PADANG INTERNATIONAL CONFERENCE OF EDUCATION MANAGEMENT AND ADMINISTRATION (PICEMA). Padang, Indonesia, 2018.

SARI, Kartika; PATIMAH, Siti. Improving the quality of human resources in Indonesia to become entrepreneurs. ONE ASIA COMMUNITY CONFERENCE, Tokyo, 2019.

SILVA, Ronison Oliveira. Proposta de autocapacitação para coordenadores de graduação. Manaus: Ifam, 2019. 137f. Dissertação (Mestrado Profissional em Educação Profissional e Tecnológica). Instituto Federal de Educação, Ciência e Tecnologia do Amazonas.

SILVA, Ronison Oliveira da; OLIVEIRA, Erinaldo Silva; SÁ FILHO, Paulo de; NASCIMENTO-E-SILVA, Daniel. O ciclo PDCA como proposta para uma gestão escolar eficiente. Regae: Rev. Gest. Aval. Educ., Santa Maria, v.8, n.17, 2019, p. 1-13.

SLACK, Nigel, Chamber, Stuart; Johnston, Robert. Administração da produção. São Paulo: Saraiva, 2009.

SOLGA, Marc von; RYSCHKA, Jurij; MATTENKLOTT, Axel. Personalentwicklung: Gegenstand, Prozessmodell, Erfolgsfaktoren. In: RYSCHKA, J. et al. Praxishandbuch personalentwicklung - instrumente, konzepte, beispiele. Springer Fachmedien. Wiesbaden, 2011.

SONDARI, Endang; ZAIMAR, Yulia Sofiani. Role of PKBM as a world partiner in improving the quality of human resources in marginal communities in the millenium era. Fator Jurnal IImiah Kependidikan, v. 6, n. 2, 2019, p. 109-118.

SURNANI, Cristina Wiwik; AMBARRIANI, Anastasia Susty. The pricing practices: management accounting perspective. Review of Integrative Business and Economics Research, v. 8, n. 2, 2019, p. 84-97.

TEMEL, Aydin; KONUK, N; TURAN, N.G; ARDALI, Y. The SWOT analysis for sustainable MSWM and minimization practices in Turkey. Global Nest Journal, v. 20, n. 1, 2018, p. 8387.

TEODORESCU, Tina. Competence versus competency: what is the difference? Performance Improvement Journal, Mitilene, v. 45, n. 10, 2006, p. 27-30.

UGWU, Michael Chukwudi; CHIEBERE, Emenari Beatrice. Factors militating agains effective library adminstration among library staff in Alex Ekwueme Library, Federal Polytechnic Oko, Ambra State. International Journal of Arts, Language and Business Studies, Okija, Anambra State, v.2, n. 2, 2019, p.170-177.

YAHYA, Omar Abu; ISMAILE, Samantha, ALLARI, Rabia S; HAMMOUDi, Baara M. Correlates of nurses motivation and their demographic characteristics. Nurs Forum, v. 54, 2019, p. 7-15. 
YUSNITA, Yeni; ERIYANTI, Fitri; ENGKIZAR, Egkizar; ANWAR, Fuady; PUTRI, Nofrina Eka; ARIFIN, Zainul; SYAFRIL, Syafrimen. The effect of professional education and training for teachers (PLPG) in improving pedagogic competence and teacher performance. Tadris: Jurnal of Keguruan dan IImu Tarbiyah, v. 3, n. 2, 2018, p. 123-130.

VIGNATI, Monia Lavra. Metáforas e sua representatividade na gestão acadêmica. Vitória: Ufes, 2019. 101f. Dissertação (Mestrado em Administração). Universidade Federal do Espírito Santo.

Ronison Oliveira da Silva tem mestrado em Educação Profissional e Tecnológica pelo Instituto Federal de Educação, Ciência e Tecnologia do Amazonas.

Orcid: https://orcid.org/0000-0003-07090-4081.

Endereço: Rua Monte Calvário, 83 - 69039-710 - Manaus - AM - Brasil.

E-mail: ronison.msc@gmail.com.

Antônio Jorge Cunha Campos é professor na Universidade Federal do Amazonas. Orcid: https://orcid.org/0000-0003-1809-3175.

Endereço: Avenida General Rodrigo Otávio, 3000 - 69060-260 - Manaus - AM Brasil.

E-mail: jorgecampos257@gmail.com.

Pedro Antônio de Melo é professor na Universidade Federal de Santa Catarina.

Orcid: https://orcid.org/0000-0001-7607-4303.

Endereço: Campus Universitário Trindade, 476 - 88040-900 - Florianópolis - SC Brasil.

E-mail: pedro.inpeau@gmail.com.

Daniel Nascimento-e-Silva é professor no Instituto Federal de Educação, Ciência e Tecnologia do Amazonas, campus Manaus Distrito Industrial.

Orcid: https://orcid.org/0000-0001-9770-575X.

Endereço: Rua André Thevet, 11 - 69098-325 - Manaus - AM - Brasil.

E-mail: danielnss@gmail.com.

Critérios de autoria: os autores participaram da concepção, execução, análise, interpretação e redação do manuscrito.

Recebido em 21 de dezembro de 2020.

Aceito em 26 de maio de 2021.

Regae: Rev. Gest. Aval. Educ.

Santa Maria

v. 10

ก. 19

e63666, p. 1-17

2021 